\title{
Trail impact monitoring in Rocky Mountain National Park, USA
}

\author{
J. Svajda ${ }^{1}$, S. Korony ${ }^{1}$, I. Brighton ${ }^{2}$, S. Esser ${ }^{2}$, and S. Ciapala ${ }^{3}$ \\ ${ }^{1}$ Matej Bel University, Banska Bystrica, Slovakia \\ ${ }^{2}$ Rocky Mountain National Park, Estes Park, Colorado, USA \\ ${ }^{3}$ Academy of Physical Education, Krakow, Poland
}

Correspondence to: J. Svajda (juraj.svajda@umb.sk)

Received: 23 October 2015 - Published in Solid Earth Discuss.: 6 November 2015

Revised: 11 January 2016 - Accepted: 13 January 2016 - Published: 26 January 2016

\begin{abstract}
This paper examines impacts of increased visitation leading to human trampling of vegetation and soil along several trails in Rocky Mountain National Park (RMNP) to understand how abiotic factors and level of use can influence trail conditions. RMNP is one of the most visited national parks in the USA, with 3.3 million visitors in 2012 across $1075 \mathrm{~km}^{2}$ and $571 \mathrm{~km}$ of hiking trails. $95 \%$ of the park is designated wilderness, making the balance between preservation and visitor use challenging. This research involves the application of trail condition assessments to $56 \mathrm{~km}$ of trails to determine prevailing factors and what, if any, connection between them exist. The study looked at a variety of inventory and impact indicators and standards to determine their importance and to develop a baseline condition of trails. The data can be used for future comparison and evaluation of development trends. We found that trail widening (mean trail width $88.9 \mathrm{~cm}$ ) and soil loss (cross-sectional area $172.7 \mathrm{~cm}^{2}$ ) are the most visible effects of trail degradation. Further statistical analyses of data identified the role and influence of various factors (e.g., use level and topography). Insights into the influence of these factors can lead to the selection of appropriate management measures to avoid or minimize negative consequences from increased visitation.
\end{abstract}

\section{Introduction and problem overview}

Recreational activities in protected areas have been increasing and have created the need to improve understanding of the impacts and management (Hammitt et al., 2015; Chrisfield et al., 2012; Monz et al., 2013). The trampling of vegetation and soil by hikers (Cole, 1989; Bright, 1986) is often a cause of land degradation in national parks. Recreational trails are often a source of negative impacts on the persistence of threatened, endangered, rare and keystone species (Ballantyne and Pickering, 2015). Trampling, especially in tundra ecosystems, may lead to altered environmental conditions, including decreased infiltration capacity and nutrient cycles in soils, and more extreme temperatures at the soil surface (Chrisfield et al., 2012). To date, large amounts of research are focused on the impact of visitors on soil and vegetation including monitoring and modeling (Dixon et al., 2004; Farell and Marion, 2001; Monti and MacKintosh, 1979; Godefroid and Koedam, 2004; Özcan et al., 2013). A variety of efficient methods for evaluating trails and their resource conditions, especially in sensitive and vulnerable areas (alpine environment), have been developed and described in the literature (Jewell and Hammitt, 2000; Hawes et al., 2006; Ólafsdótirr and Runnström, 2013; Tomczyk and Ewertowski, 2011; Brevik and Fenton, 2012). A review by Marion and Leung (2001) concluded that the point sampling method provides accurate and precise measures of trail characteristics that are continuous or frequent (e.g., tread width). Ground-based surveys are fairly accurate (with GPS), use existing staff and resources and provide immediate results. However, there are also some limitations of point sampling techniques - e.g., time consumption (Hill and Pickering, 2009).

Parks and protected areas are often set aside for conservation and recreational purposes, and have become some of the most sought-after vacation areas in the world, creating conflicts between conservation and recreation. In the US, National Park Service (NPS) units receive approximately 280 million visitors per year (IRMA, 2014). Couple this extensive visitation with the mission of the NPS, which is to protect and preserve both natural and cultural resources while 
providing for the freest opportunities for public enjoyment and recreation, and conflict between conservation issues and visitor use occur. Striking a balance between these competing goals often forces land managers to make compromises between impacts from visitation and protection of resources.

Parks apply a wide range of tools and techniques to manage impacts from visitor use. By providing a network of formal trails, protected areas can limit negative trampling impacts and prevent widespread degradation that would be caused by a less structured pattern of visitor activity and traffic (Marion et al., 2011). To balance resource protection and visitor experience, several frameworks have been developed to guide management decisions (Manning, 1999). These frameworks use numerical standards for biophysical or social condition indicators and set limits to define the critical threshold between an acceptable and unacceptable change in resources and social conditions (Kim and Shelby, 2006). Baseline data and future monitoring can also be used to compare past conditions with future conditions. If actual conditions are above quantitatively defined standards, managers can effectively deal with these factors to improve or stabilize the conditions. Such visitor impact monitoring programs can provide managers reliable information necessary to evaluate resource protection policies, trends, strategies and measures (Vistad, 2003). However, many authors have stated that the impacts of visitors on the ecological conditions of an area are influenced more by visitor behavior, park infrastructure and the resilience of soil and vegetation, and are less related to overall use levels (McCool and Lime, 2001). For example sustainable usage levels depend on a range of factors, including extent of trail hardening and frequency of trail maintenance (Washburn, 1982).

To better understand use and associated resource impacts, a visitor and trail monitoring program needs a diverse set of indicators that evaluate changes over time (Leung and Marion, 2000). Most commonly used trail indicators include the number, length and density of visitor-created trails, along with tread. Soil loss, the most ecologically significant trail impact, is less common, though it can be efficiently determined by measuring maximum incision or cross-sectional area at points along the trail (Olive and Marion, 2009). Other problems include visitors participating in a variety of recreation activities (hiking, camping, horseback riding), each of which contributes a unique impact on natural resources (vegetation, soil, water, wildlife). Some authors have compared and assessed the impacts of different recreation activities (hiking, mountain biking, horse riding) on vegetation and soils (e.g., Pickering et al., 2010; Wilson and Seney, 1994). There is limited research on the ecological impacts of tourism and recreation in some parts of the world (Barros et al., 2015; Zdruli, 2014; Ibáñez et al., 2015). Existing studies document a range of impacts on vegetation, birds and mammals, including changes in plant species richness, composition and vegetation cover and the tolerance of wildlife to visitor use. Comparable studies, especially in high alpine en- vironments, are needed to predict the effects of topographic and climatic extremes (Nepal, 2003).

Conducting formal trail surveys provides information for a number of important management questions and decisions, though it is commonly overlooked due to funding constraints. Information about trail conditions can be used to inform the public about trail status, justify staffing and financing, evaluate the acceptability of existing resource conditions, understand relationships between trail impacts and the controlling mechanism, identify and select appropriate management actions and determine the effectiveness of implemented actions. This paper presents research and assessment of impacts on the trail network of the Rocky Mountain National Park (RMNP) study area to understand how abiotic factors such as grade, elevation, surface type and trail slope alignment can influence trail conditions. We also want to understand how visitation type (e.g., people vs. horses) and level of use can impact trails. Finally, our last goal is to determine which factors are prevailing and what connection between factors exist. This would help managers reduce the effects of visitor use on natural resources of the park.

\section{Study area}

Rocky Mountain National Park (RMNP) is located in northern Colorado (USA), comprises an area of $1075 \mathrm{~km}^{2}$ and provides access to wild places for visitors to recreate and experience solitude and outstanding beauty (Fig. 1). The elevation range within the park spans from 2316 to $4346 \mathrm{~m}$, which creates a highly complex and steep topographic gradient, allowing for diverse vegetation communities. The underlying geology of this mountain is also highly complex, though it is primarily granitic. Severe climatic conditions and thin soils have created a fragile environment at higher elevations throughout the park (alpine tundra encompasses onethird of the park area) that is neither resistant nor resilient to human use (RMNP, 2013). The historical annual temperature average (1900-2002) is $1.5^{\circ} \mathrm{C}$, and the annual average precipitation for the same period is $400 \mathrm{~mm} \mathrm{yr}^{-1}$. Over the past several decades temperatures have been increasing $+0.8^{\circ}$ century $^{-1}$ (Gonzalez, 2012) and precipitation patterns have been highly variable, with increased drought years followed by extreme rain events and record snowpacks, causing varying degrees of freeze/thaw actions and greater spring runoff events.

Yearly visitation over the past decade has hovered around 3 million visitors a year, with the total number of recreation visitors in 2012 being 3.3 million. The busiest tourist season is the summer months (June-August), but in recent years, the heaviest visitation days have occurred during the weekends of late summer and early fall due to the elk rut and foliage change. Overnight as well as day use has steadily increased over the past several decades, resulting in more impacts from visitation (RMNP, 2001). 


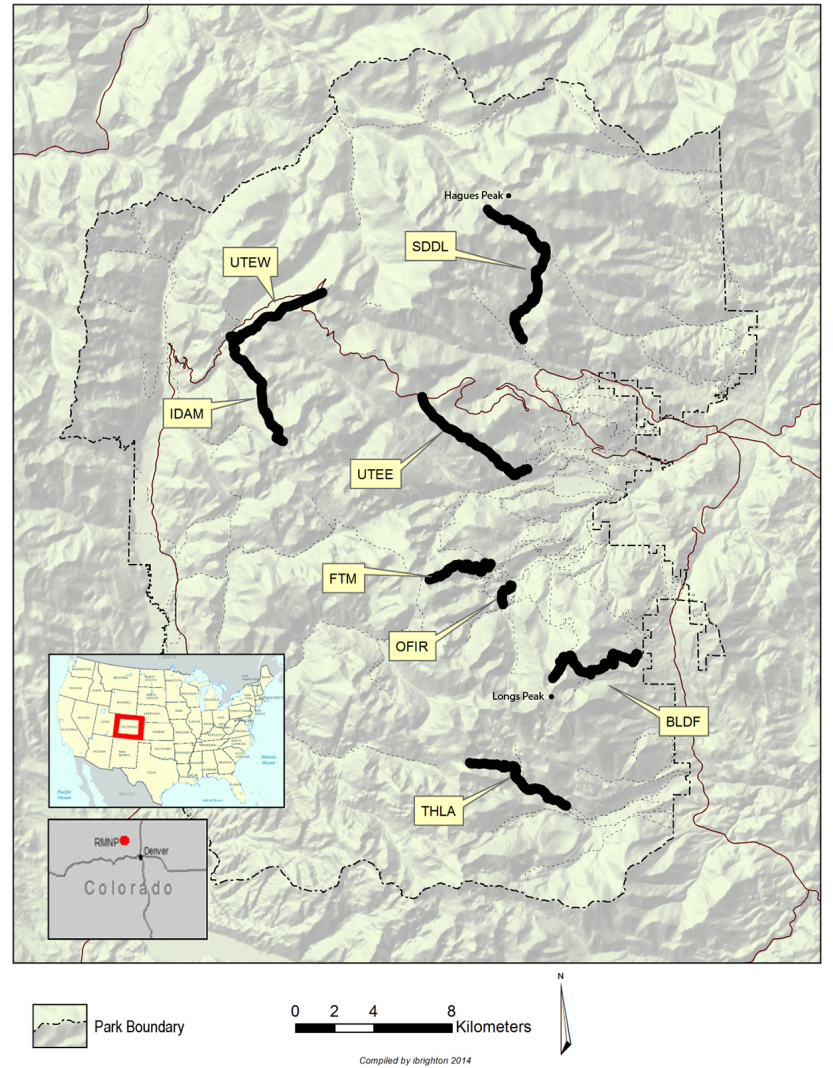

Figure 1. Study area showing all eight evaluated trails - abbreviations of the names of trails: Saddle (SDLL), Ute West (UTEW), Mount Ida (IDAM), Ute East (UTEE), Flattop Mountain (FLTM), Old Fire (OFIR), Boulder Field (BLDF) and Thunder Lake (THLA).

Monitoring visitor use focused on vegetation and soil impacts is important in alpine areas, climbing areas and riparian areas where the information can help with determining thresholds of degradation (NPS, 2010). The loss of soil and vegetation from high use and unacceptable behavior of visitors are a principal concern. Besides educating visitors about principles (e.g., staying on the trail) and monitoring visitor use numbers, the results of this research can help inform park managers.

Early studies focused on the impact of visitors on natural ecosystems in RMNP (e.g., Willard and Marr, 1963) and stated the need to develop a system of evaluating day use destination sites, document trends in day use, develop guidelines, install flip signs, voluntary permits or a self-registration system and set concrete use limits (e.g., for parking). Later works are devoted especially to the monitoring of trail impacts (Summer, 1986; Benninger-Truax et al., 1992; KellerLynn, 2006; Pettebone et al., 2009).

Approximately $571 \mathrm{~km}$ of hiking trails provides visitors with recreation opportunities throughout the park (RMNP, 2013; Fig. 1). Some of the current trail system evolved from game trails used by Native Americans, then explorers and herders and was finally adopted by the National Park Service. A lot of the trails were built or improved by the Civilian Conservation Corps (CCC) during the 1930s. These trails span the entire elevation gradient, running across valley bottoms and ridgetops. RMNP is divided into ten planning units based on similar physiographic features and visitor use patterns (RMNP, 2000). Evaluated trails are situated in several planning units (Fig. 1; Front Range, Longs Peak, Wild Basin, Roaring River, Trail Ridge). Each planning unit is specified with trail project priorities (safety of visitors, mitigation of resource damage) and cost estimates. Since 2008 there have been new Federal Trail Data Standards, which include four fundamental concepts that are cornerstones of effective trail planning and management (trail type, trail class, managed use, designed use). Although not entirely new, these interagency concepts provide an integrated means to consistently record and communicate the intended design and management guidelines for trail design, construction, maintenance and use.

\section{Methods and analysis}

During August 2013, we applied impact assessment procedures to eight formal and informal trails $(56 \mathrm{~km})$ within RMNP. They represent a subset of the entire trail system and were selected because they provide a unique look at the variation of impacts along an elevation gradient and visitor use gradient, while representing the greatest possible spatial extent of RMNP. Some of the trails (or sections of trails) are used not only by hikers but also by other user groups such as equestrians (about $80 \%$ of the total trails maintained in the park are open to commercial and private stock use). Four trails were evaluated on the north side of the park: Saddle trail (SDDL), Ute trail West (UTEW), Ute trail East (UTEE) and Mount Ida trail (IDAM), three on the south side of the park: Flattop Mountain trail (FLTM), Boulder Field trail (BLDF) and Thunder Lake trail (THLA). Also one short section of an informal trail, Old Fire trail (OFIR), was measured with detailed sampling (30.5 m interval) - see Table 1a, b and Fig. 2 .

\subsection{Trail sampling}

Trail sampling for each of the eight trails involved taking replicable measurements at a number of determined locations in order to calculate overall estimations of trail conditions. We used point sampling methods to generate accurate and precise data on trails' conditions (Marion et al., 2011). This was used to develop useful and appropriate baseline data to monitor selected environmental indicators and standards of quality. A $152 \mathrm{~m}$ point sampling interval, determined using GPS (Garmin GPSmap 60 CSx) and a measuring wheel (Rolatape RSL 204-5), was selected and employed based on 
Table 1. (a) Inventory and (b) impact indicators summarized by trails. Use levels: L refers to low, M refers to medium, H refers to high; use types: F refers to foot, A refers to all hikers and horse riders.

\begin{tabular}{|c|c|c|c|c|c|c|c|c|c|c|}
\hline \multicolumn{11}{|l|}{ (a) Inventory indicators } \\
\hline \multirow[t]{2}{*}{ Trail section } & Length & $\begin{array}{l}\text { Sample } \\
\text { count }\end{array}$ & $\begin{array}{l}\text { Elevation } \\
\text { (ma.s.1.) }\end{array}$ & $\begin{array}{r}\text { Trail } \\
\text { grade }(\%)\end{array}$ & $\begin{array}{l}\text { Landform } \\
\text { grade }(\%)\end{array}$ & $\begin{array}{r}\text { Slope } \\
\text { alignment } \\
\text { angle }\left(^{\circ}\right)\end{array}$ & \multirow[t]{2}{*}{$\begin{array}{l}\text { Use } \\
\text { levels }\end{array}$} & \multirow[t]{2}{*}{$\begin{array}{r}\text { Use } \\
\text { types }\end{array}$} & $\begin{array}{l}\text { Slope } \\
\text { ratio }\end{array}$ & \multirow{2}{*}{$\begin{array}{r}\begin{array}{r}\text { Rugosity } \\
(\mathrm{cm})\end{array} \\
\text { Mean }\end{array}$} \\
\hline & $\mathrm{km}$ & $N$ & Mean & Mean & Mean & Mean & & & Mean & \\
\hline Ute trail West & 6.55 & 43 & 3477 & 8 & 23 & 67 & M & $\mathrm{F}$ & 0.42 & 2.74 \\
\hline Boulder Field trail & 8.90 & 57 & 3458 & 9 & 19 & 53 & $\mathrm{H}$ & A & 0.53 & 3.05 \\
\hline Flattop Mountain trail & 5.78 & 36 & 3417 & 13 & 20 & 56 & $\mathrm{H}$ & A & 0.64 & 2.97 \\
\hline Mount Ida trail & 8.13 & 46 & 3657 & 13 & 27 & 63 & $\mathrm{~L}-\mathrm{M}$ & $\mathrm{F}$ & 0.57 & 2.90 \\
\hline Saddle trail & 11.84 & 76 & 3220 & 12 & 20 & 53 & $\mathrm{~L}-\mathrm{M}$ & $\mathrm{A}$ & 0.65 & 2.36 \\
\hline Thunder Lake trail & 7.63 & 50 & 3171 & 13 & 25 & 54 & $\mathrm{~L}-\mathrm{M}$ & A & 0.80 & 2.39 \\
\hline Ute trail East & 6.60 & 53 & 3218 & 12 & 21 & 50 & $\mathrm{~L}$ & $\mathrm{~F}$ & 0.56 & 3.00 \\
\hline Trail system mean & 7.92 & & 3374 & 11 & 22 & 56 & & & 0.60 & 2.77 \\
\hline Standard deviation & 2.03 & & 177 & 9 & 12 & 20 & & & 0.86 & 0 \\
\hline Old Fire trail & 1.42 & 48 & 2932 & 12 & 22 & 55 & $\mathrm{H}$ & $\mathrm{F}$ & 0.53 & 2.16 \\
\hline \multicolumn{11}{|l|}{ (b) Impact indicators } \\
\hline \multirow[t]{2}{*}{ Trail section } & \multicolumn{2}{|c|}{$\begin{array}{l}\text { Trail width } \\
\quad(\mathrm{cm})\end{array}$} & \multicolumn{2}{|c|}{$\begin{array}{l}\text { Width difference } \\
\qquad(\mathrm{cm})\end{array}$} & \multicolumn{2}{|c|}{$\begin{array}{l}\text { CSA } \\
\left(\mathrm{cm}^{2}\right)\end{array}$} & \multicolumn{2}{|c|}{$\begin{array}{l}\text { Maximum incision } \\
(\mathrm{cm})\end{array}$} & & \\
\hline & \multicolumn{2}{|c|}{ Mean } & \multicolumn{2}{|c|}{ Mean } & \multicolumn{2}{|c|}{ Mean } & \multicolumn{2}{|c|}{ Mean } & & \\
\hline Ute trail West & \multicolumn{2}{|c|}{100.58} & \multicolumn{2}{|c|}{54.86} & \multicolumn{2}{|c|}{452} & \multicolumn{2}{|c|}{7.19} & & \\
\hline Boulder Field & \multicolumn{2}{|c|}{115.32} & \multicolumn{2}{|c|}{23.88} & \multicolumn{2}{|c|}{671} & \multicolumn{2}{|c|}{8.64} & & \\
\hline Flattop Mountain trail & \multicolumn{2}{|c|}{115.37} & \multicolumn{2}{|c|}{23.93} & \multicolumn{2}{|c|}{606} & \multicolumn{2}{|c|}{8.41} & & \\
\hline Mount Ida trail & \multicolumn{2}{|c|}{56.26} & \multicolumn{2}{|c|}{10.54} & \multicolumn{2}{|c|}{297} & \multicolumn{2}{|c|}{6.78} & & \\
\hline Saddle trail & & 91 & & 11 & & & & & & \\
\hline Thunder Lake trail & & .50 & & 18 & & & & & & \\
\hline Ute trail East & & .50 & & 78 & & & & & & \\
\hline Trail system mean & & 35 & & 61 & & & & & & \\
\hline Standard deviation & & 47 & & 04 & & & & & & \\
\hline Old Fire trail & & .15 & & 43 & & & & & & \\
\hline
\end{tabular}

the findings, efficiency and feasibility of replication and was thought to best represent the length of each trail. This interval provided the appropriate number of sample points, allowing statistical analysis and the ability to characterize trail conditions.

\subsection{Trail condition indicators}

At each sample point, a single transect was established perpendicular to the trail tread, with endpoints defined by the most visually obvious outer boundary of trampling-related disturbance. These boundaries are defined by pronounced changes in ground vegetation height (trampled vs. untrampled), cover, composition or when vegetation cover is reduced or absent and by disturbance to organic litter or lichen (intact vs. pulverized). We adopted criteria described by Monz (2000) and Lance et al. (1989) for measurement consideration and definition of the trail tread boundaries of the trail as receiving the majority $(>95 \%)$ of traffic (Marion et al., 2011). To assess trail width, the distance between these disturbance-associated boundaries was measured with a tape rule (Stanley Lever Lock $25^{\circ}$ ). The difference between intended vs. actual trail widths was assessed as trail width difference according to trail data standards. Additionally the grade of the trail and the dominant fall line (landform grade) was recorded at each transect location.

Trail slope alignment angle (TSA) was assessed at each sample point as the difference in compass bearing between the prevailing landform slope orientation (i.e., aspect) and the trail's alignment at the sample point. For example, the TSA of a contour-aligned trail would equal $90^{\circ}$, while a true fall-line trail (aligned congruent to the landform slope) would have a TSA of $0^{\circ}$. Trail grade, trail slope and alignment angle were measured using a clinometer and compass (Suunto Tandem). The quotient of trail grade and landform grade was calculated as a slope ratio (IMBA, 2004). To assess tread surface composition we used the following categories: bare soil, vegetation, organic litter, roots, rock and gravel, wood and 

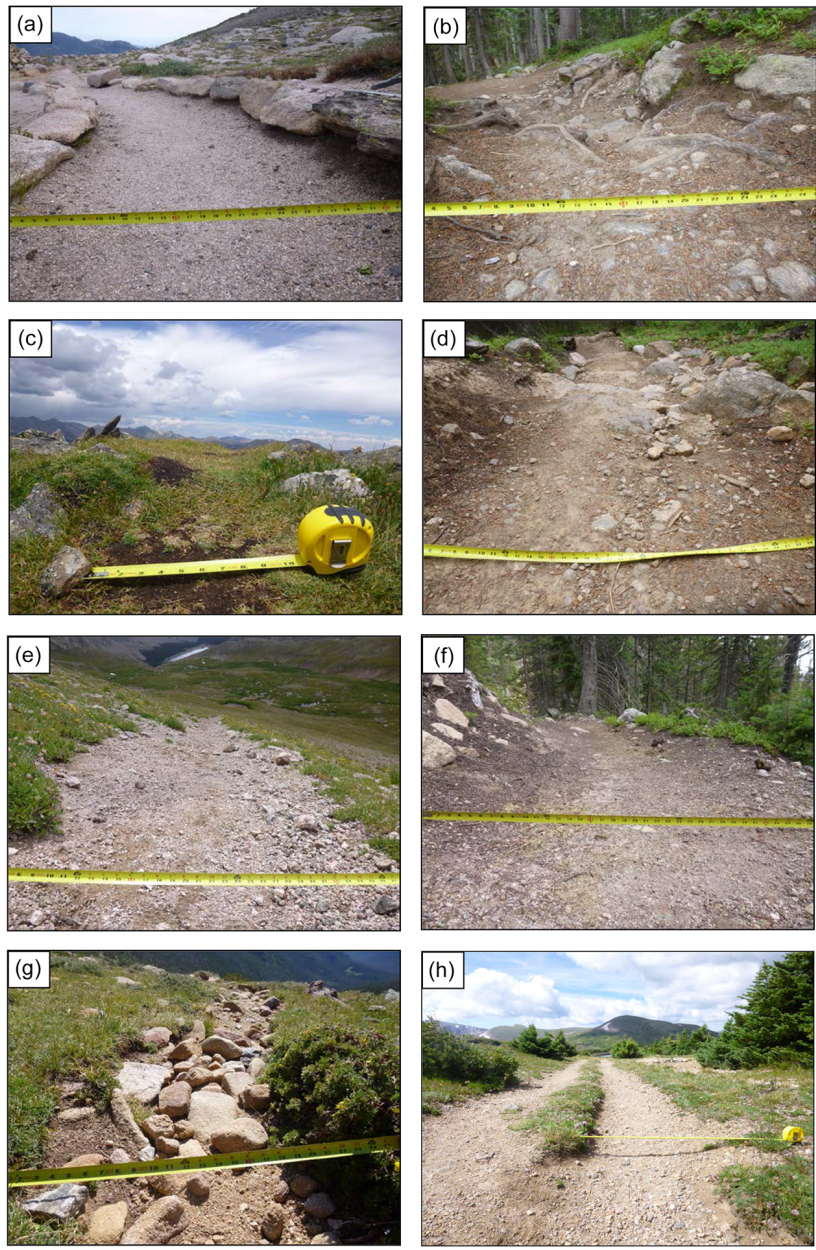

Figure 2. (a) Use of natural materials to limit the trail can prevent it from widening and formation of secondary trails - BLDF. (b) Change of tread substrate characteristics is connected also with elevation - in the forest zone, exposed tree roots are more commonly found - FLTM. (c) The highest sections of IDAM are barely recognizable due to very small visitation. (d) OFIR is an example of a social trail with high traffic; some sections were maintained in the past. (e) One of the typical examples of how orientation and slope of trail have impacted on the width of the trail - SDDL. (f) THLA is used by hikers and stock as well - one of the effects is expansion of the width and depth of the trail with the consequent loss of soil. (g) UTEE - a problem with erosion is notable, particularly in the section down from Timberline Pass. (h) Secondary treads are more common in areas with lower grades - UTEW.

man-made materials. For each category, the percent of trail width was recorded to the nearest $10 \%$. An occurrence of additional secondary trails that paralleled the survey trail at each sample point was marked as well as previous remarkable side-hill construction work at each sample point.

To determine whether there was soil loss $\left(\mathrm{cm}^{2}\right)$ at a sample point, we employed a fixed interval method crosssectional area (CSA) analysis, adopted from Cole (1983) and described as the variable CSA method (Olive and Mar- ion, 2009). To establish a cross section, temporary stakes were placed at positions that enabled a cord measure to be stretched along what was believed to represent the original land surface for fall-line trails or the post-construction tread surface for constructed side-hill trails. Vertical measurements from the cord measure to the trail substrate surface were taken at a fixed interval of $12 \mathrm{~cm}$ for all trails. This measure included soil loss from water or wind erosion, soil compaction of the trail substrates and soil displacement from traffic. CSA was calculated for each sample point using spreadsheet formulas in Microsoft Excel, where $V$ is the vertical distance measurements and $L$ is the interval on the horizontal taut line (Cole, 1983). Trail condition measures were calculated for each trail and for all trails combined, including area of disturbance, CSA and mean trail width and depth.

$\mathrm{CSA}=\frac{\left(V_{1}+2 V_{2}+\ldots+2 V_{n}+V_{n+1}\right)}{2 \times L}$

The ruggedness or roughness of the trail surface was calculated for each sample point from measurements taken to compute CSA estimates as the standard deviation of the vertical measurement at each transect. To ensure repeatability of this work, digital photographs were taken with a camera (Panasonic DMC-SZ1, 16.1 megapixel resolution) along with recording GPS coordinates at each transect for all future resampling events which occur along the same transects. Photographs were also utilized to create two additional attributes for each trail transect - trail substrate class and trail borders. Based on field observation by trail maintenance staff, use levels (high > 100 users a day; medium 50 100 users a day; low $<50$ users a day) and type of use (hiking only/hiking + stock use) were assigned to each trail segment. Elevation of each sample point was recorded and three main categories according vegetation cover created: above $3505 \mathrm{~m}$ a.s.l. alpine tundra, 3505-2896 m a.s.l. spruce/fir and below $2896 \mathrm{~m}$ a.s.l. lodgepole pine (RMNP, 2001).

\subsection{Data analysis}

Spatial data were transferred from GPS to EasyGPS and maps were created in ArcGIS Desktop and ArcMap 10.2 applications. Statistical data were transferred to Microsoft Excel and to statistical system SPSS 19 for further analysis. Originally, all suitable statistical procedures (ANOVA, nonparametric ANOVA Kruskal-Wallis test, two-sample MannWhitney test, correlations (both classic Pearson and robust Spearman) and linear regression analyses) were performed to investigate relationships between dependent and independent variables. Nonparametric tests were used because the data do not meet normality assumptions. Analysis focused primarily on understanding the dependent variables of interest: trail width and CSA soil loss. Linear regression modeling as dependence of soil loss variables to grade variables was done, but the results were unsatisfactory (e.g., regression coefficient of determination below $10 \%$ ). That is why we 
Table 2. Number and percent of sample points by inventory indicator category.

\begin{tabular}{|c|c|c|}
\hline Grade & $\begin{array}{r}\text { Number of } \\
\text { sample points }\end{array}$ & Percentage \\
\hline $0-2 \%$ & 46 & 12.74 \\
\hline $2-6 \%$ & 78 & 21.61 \\
\hline $6-10 \%$ & 83 & 22.99 \\
\hline $10-15 \%$ & 67 & 18.56 \\
\hline $15-20 \%$ & 38 & 10.53 \\
\hline $20-30 \%$ & 31 & 8.59 \\
\hline $30-100 \%$ & 18 & 4.99 \\
\hline Totals & 361 & 100 \\
\hline \multicolumn{3}{|c|}{ Mean $=11.4 \% ;$ median $=9 \% ;$ range $=0-100 \%$} \\
\hline Slope alignment & $\begin{array}{r}\text { Number of } \\
\text { sample points }\end{array}$ & Percentage \\
\hline $0-22^{\circ}$ & 23 & 6.37 \\
\hline $22-45^{\circ}$ & 92 & 25.48 \\
\hline $45-68^{\circ}$ & 118 & 32.69 \\
\hline $68-90^{\circ}$ & 128 & 35.46 \\
\hline Totals & 361 & 100 \\
\hline \multicolumn{3}{|c|}{ Mean $=55.9^{\circ} ;$ median $=60^{\circ} ;$ range $=0-90^{\circ}$} \\
\hline Elevation & $\begin{array}{r}\text { Number of } \\
\text { sample points }\end{array}$ & Percentage \\
\hline 2743-2896 m a.s.1. (lodgepole pine) & 22 & 6.09 \\
\hline 2896-3505 m a.s.1. (spruce/fir) & 209 & 57.89 \\
\hline 3505-3962 m a.s.1. (alpine tundra) & 130 & 36.01 \\
\hline Totals & 361 & 100 \\
\hline \multicolumn{3}{|c|}{ Mean $=3356.7 \mathrm{~m}$ a.s.1.; median $=3385.4 \mathrm{~m}$ a.s.1.; range $=2743-3962 \mathrm{~m}$ a.s.1. } \\
\hline
\end{tabular}

also tested robust nonparametric data mining decision trees implemented in SPSS to gain multivariate models of tread widths vs. all relevant indicators. In SPSS there are three types of decision trees: CHAID, CRT and QUEST. For our purpose, CRT (classification and regression tree) appeared to be the most suitable. From all used potential indicators of tread width, five indicators are used in CRT: use level, name of trail, trail substrate - vegetation, elevation and maximum incision.

\section{Results}

\subsection{Trail condition indicators}

We assessed 361 sample points along a total length of $55.43 \mathrm{~km}$ for seven trails within RMNP. One short informal trail $(1.42 \mathrm{~km}, 48$ points) was surveyed, though we excluded this trail from the overall statistical analyses since sampling methods differed slightly.

Approximately $13 \%$ of the trails are located on flat terrain (0-2\% grade), $24 \%$ of the trail system has grades exceeding $15 \%$ and only $5 \%$ of the trails have grades exceeding $30 \%$. The mean grade of trails is $11.4 \%$. It should be noted that many of the excessively steep alignments have constructed rock steps or ascend exposed rock faces, which are not susceptible to soil loss. Regarding the trail's slope alignment angle, only $6 \%$ of trails are aligned within $22^{\circ}$ of the landform
Table 3. Number and percent of sample points by impact indicator category.

\begin{tabular}{|c|c|c|}
\hline Indicator & Sample points & Percentage \\
\hline \multicolumn{3}{|c|}{ Trail width (cm) } \\
\hline $0-61$ & 75 & 20.78 \\
\hline $61-91$ & 128 & 35.46 \\
\hline $91-122$ & 108 & 29.92 \\
\hline $122-152$ & 39 & 10.80 \\
\hline$>152$ & 11 & 3.05 \\
\hline \multicolumn{3}{|c|}{ Mean $=89.9 ;$ median $=88.9 ;$ range $=0-193$} \\
\hline \multicolumn{3}{|c|}{ Trail width difference $(\mathrm{cm})$} \\
\hline-76 to -15 & 15 & 4.16 \\
\hline-15 to +15 & 143 & 39.61 \\
\hline $15-76$ & 190 & 52.63 \\
\hline $76-152$ & 13 & 3.60 \\
\hline \multicolumn{3}{|c|}{ Mean $=22.6 ;$ median $=20.3 ;$ range $=-45$ to +147} \\
\hline \multicolumn{3}{|c|}{ Maximum incision (cm) } \\
\hline 0 & 3 & 0.83 \\
\hline $0-1.3$ & 1 & 0.28 \\
\hline $1.3-2.5$ & 16 & 4.43 \\
\hline $2.5-7.6$ & 209 & 57.89 \\
\hline $7.6-12.7$ & 107 & 29.64 \\
\hline \multicolumn{3}{|c|}{ Mean $=7.1 ;$ median $=6.3 ;$ range $=0-19$} \\
\hline \multicolumn{3}{|c|}{ CSA soil loss $\left(\mathrm{cm}^{2}\right)$} \\
\hline 0 & 3 & 0.83 \\
\hline $0-645$ & 291 & 80.61 \\
\hline $645-1290$ & 61 & 16.90 \\
\hline$>1290$ & 6 & 1.66 \\
\hline \multicolumn{3}{|c|}{ Mean $=444.5 ;$ median $=387 ;$ range $=0-1509.6$} \\
\hline \multicolumn{3}{|c|}{ Mean trail depth $(\mathrm{cm})$} \\
\hline 0 & 3 & 0.83 \\
\hline $0.0-1.3$ & 7 & 1.94 \\
\hline $1.3-2.5$ & 76 & 21.05 \\
\hline $2.5-7.6$ & 251 & 69.53 \\
\hline $7.6-12.7$ & 23 & 6.37 \\
\hline$>12.7$ & 1 & 0.28 \\
\hline
\end{tabular}

Mean $=4.1 ;$ median $=3.8 ;$ range $=0-12.9$

aspect or fall line. The mean elevation of the evaluated points is $3356.7 \mathrm{~m}$ a.s.l. (Table 2).

The trail width maximum is $193 \mathrm{~cm}$, with a mean of $89.9 \mathrm{~cm}$. Fewer than $14 \%$ of the trails exceed $120 \mathrm{~cm}$ in width. The mean trail width difference was $56.9 \mathrm{~cm}$, indicating that trails are generally wider than intended by trail data standards. Incision ranged from 0 to $19.1 \mathrm{~cm}$, with a mean of $7.1 \mathrm{~cm}$. Cross-sectional area soil loss measurements (CSA) ranged from 0 to $1510 \mathrm{~cm}^{2}$, with a mean of $444.5 \mathrm{~cm}^{2}$. A more representative measure of trail incision is provided by calculating the mean trail depth from the vertical measures 


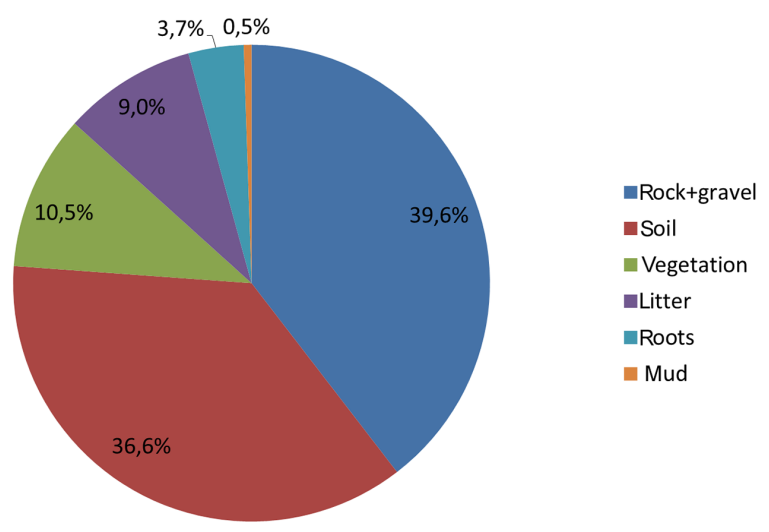

Figure 3. Mean trail substrate cover as a proportion of transect (tread) width.

recorded to compute CSA. This measure ranged from 0 to $12.9 \mathrm{~cm}$, with a mean of $4.1 \mathrm{~cm}$ (Table 3 ).

Finally, assessments of the tread substrate as a proportion of transect width are used to characterize the typical trail system substrates described in Fig. 3.

\subsection{Trail conditions by classic analyses}

Results for different use level (low-medium-high) are highly significant for medians of trail width $(63.5$ vs. 96.5 vs. $114.3 \mathrm{~cm}$ ), maximum incision ( 5.7 vs. 6.3 vs. $7.6 \mathrm{~cm}$ ) and soil loss $\left(251.6\right.$ vs. 393.5 vs. $\left.574.2 \mathrm{~cm}^{2}\right)$; Kruskal-Wallis test, $p<0.001$. An increased visitor use leads to greater mean values of width, soil loss and maximum incision of trail (medians of maximum incision for low and middle use level are not different). Difference of tread width difference by use level was not significant (17.8 vs. 20.3 vs. 22.9 cm, KruskalWallis test, $p=0.06$, see Table 4 and Fig. 4). When looking at side-hill trails, there is a higher median of tread width (109 vs. $86 \mathrm{~cm}$; Wilcoxon test, $p<0.001$ ). The difference of maximum incision for side-hill trails is not significant (6.40 vs. $7.30 \mathrm{~cm}$, Wilcoxon test, $p=0.234)-$ see Table 4 . When comparing two groups of visitors (hikers and horseback riders), the Wilcoxon test resulted in medians that were greater for horseback riders: trail width (109.2 vs. $66 \mathrm{~cm} ; p<0.001)$; maximum incision ( 7 vs. $6.4 \mathrm{~cm} ; p=0.021)$ and soil loss ( 483.9 vs. $296.8 \mathrm{~cm}^{2} ; p<0.001$ ). Contrary to this, tread width differences were smaller for horseback riders than hikers (17.8 vs. $20.3 \mathrm{~cm}$; Wilcoxon test $p=0.011)$ - see Table 4 .

From the dependencies, it was identified that the greater incidence of secondary treads is connected with a higher median of trail slope ratio (0.69 vs. 0.50 ; Wilcoxon test, $p=0.021)$ and lower median of trail slope alignment (50 vs. $60^{\circ}$; Wilcoxon test, $\left.p=0.020\right)$. Difference of trail grade for secondary treads is not significant ( 9 vs. $10 \%$, Wilcoxon test, $p=0.348$ ) - see Table 5 .

Rugosity can strongly influence existence of secondary treads and trail width. After analyses, we only confirmed
Table 4. Summary statistics of tread width (TW), tread width difference (DIF), maximum incision (MIC) and soil loss (CSA) by use level, side-hill trails and use type. SD refers to standard deviation.

\begin{tabular}{|c|c|c|c|c|c|}
\hline Use level & & TW & DIF & MIC & CSA \\
\hline \multirow{6}{*}{ Low } & $N$ & 141 & 141 & 141 & 141 \\
\hline & Mean & 63.5 & 17.8 & 6.65 & 316.1 \\
\hline & Median & 63.5 & 17.8 & 5.71 & 251.6 \\
\hline & SD & 21.6 & 21.6 & 3.48 & 223.8 \\
\hline & Minimum & 0 & 45.7 & 0.00 & 0 \\
\hline & Maximum & 127 & 81.3 & 19.05 & 1051.6 \\
\hline \multirow{6}{*}{ Middle } & $N$ & 127 & 127 & 127 & 127 \\
\hline & Mean & 101.6 & 27.9 & 6.76 & 445.2 \\
\hline & Median & 96.5 & 20.3 & 6.35 & 393.5 \\
\hline & SD & 26.9 & 33.8 & 2.97 & 242.6 \\
\hline & Minimum & 35.6 & 25.4 & 1.90 & 90.3 \\
\hline & Maximum & 193.0 & 147.3 & 17.78 & 1509.7 \\
\hline \multirow{6}{*}{ High } & $N$ & 93 & 93 & 93 & 93 \\
\hline & Mean & 114.3 & 22.9 & 8.56 & 645.2 \\
\hline & Median & 114.3 & 22.9 & 7.62 & 574.2 \\
\hline & SD & 19.8 & 19.8 & 3.20 & 285.8 \\
\hline & Minimum & 78.7 & 12.7 & 3.17 & 251.6 \\
\hline & Maximum & 162.6 & 71.1 & 17.14 & 1490.3 \\
\hline \multicolumn{6}{|c|}{ Side-hill trails } \\
\hline \multirow{6}{*}{ No } & $N$ & 315 & 315 & 315 & 315 \\
\hline & Mean & 87.2 & 21.9 & 7.1 & 424.9 \\
\hline & Median & 86.4 & 20.3 & 6.4 & 380.6 \\
\hline & SD & 32.4 & 26.7 & 3.3 & 266.1 \\
\hline & Minimum & 0 & -45.7 & 0 & 0 \\
\hline & Maximum & 193.0 & 147.3 & 19.1 & 1451.6 \\
\hline \multirow{6}{*}{ Yes } & $N$ & 46 & 46 & 46 & 46 \\
\hline & Mean & 108.8 & 27.3 & 7.9 & 578.1 \\
\hline & Median & 109.2 & 22.9 & 7.3 & 493.5 \\
\hline & $\mathrm{SD}$ & 22.4 & 24.6 & 3.7 & 328.3 \\
\hline & Minimum & 66.0 & -12.7 & 2.5 & 129.0 \\
\hline & Maximum & 177.8 & 132.1 & 17.8 & 1509.7 \\
\hline \multicolumn{6}{|l|}{ Use type } \\
\hline \multirow{6}{*}{ A } & $N$ & 171 & 171 & 171 & 171 \\
\hline & Mean & 109.6 & 18.1 & 7.6 & 547.6 \\
\hline & Median & 109.2 & 17.8 & 7.0 & 483.9 \\
\hline & $\mathrm{SD}$ & 20.8 & 20.8 & 3.1 & 283.4 \\
\hline & Minimum & 66.0 & -25.4 & 1.9 & 90.3 \\
\hline & Maximum & 185.4 & 94.0 & 17.1 & 1490.3 \\
\hline \multirow{6}{*}{$\mathrm{F}$} & $N$ & 190 & 190 & 190 & 190 \\
\hline & Mean & 72.3 & 26.5 & 6.8 & 351.5 \\
\hline & Median & 66.0 & 20.3 & 6.4 & 296.8 \\
\hline & SD & 30.1 & 30.1 & 3.4 & 240.2 \\
\hline & Minimum & 0 & -45.7 & 0 & 0 \\
\hline & Maximum & 193.0 & 147.3 & 19.1 & 1509.7 \\
\hline
\end{tabular}



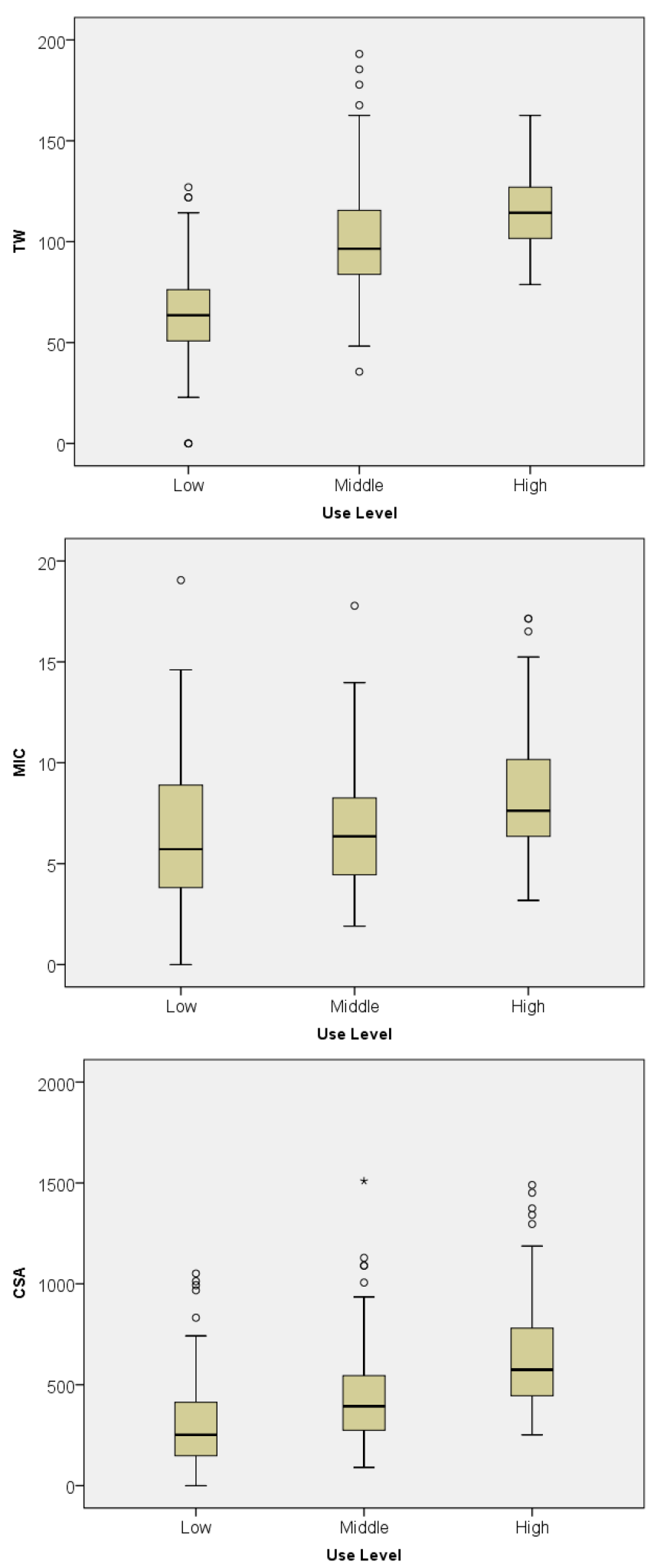

Figure 4. Box plots of trail width (TW), maximum incision (MIC) and soil loss (CSA) values for three levels of trail use.
Table 5. Summary statistics of trail grade (TG), trail slope ratio (TSR) and trail slope alignment angle (TSA) by secondary treads. SD refers to standard deviation.

\begin{tabular}{llrrr}
\hline ST & & TG & TSR & TSA \\
\hline \multirow{4}{*}{ No } & $N$ & 312 & 312 & 312 \\
& Mean & 11 & 0.59 & 57 \\
& Median & 9 & 0.50 & 60 \\
& SD & 9 & 0.92 & 20 \\
& Minimum & 0 & 0 & 10 \\
& Maximum & 59 & 15.00 & 90 \\
\hline \multirow{4}{*}{ Yes } & Mean & 49 & 49 & 49 \\
& Median & 12 & 0.66 & 50 \\
& SD & 9 & 0.69 & 50 \\
& Minimum & 0 & 0.38 & 19 \\
& Maximum & 43 & 2.00 & 20 \\
& & & & \\
\hline
\end{tabular}

significant dependence for some trails (e.g., Mann-Whitney test showed dependence of rugosity vs. secondary treads occurrence on Ute West trail and linear dependence on Mount Ida trail between rugosity and trail width). We need to highlight that results for each of the trails are not the same for all variables, so any generalization and subsequent interpretation must be cautious and exercised with respect to local conditions (e.g., in case of previous results existence of natural or human-induced barriers along trails which prevent trail widening) and a number of sample points.

When soil loss was analyzed more deeply, correlation coefficients showed no meaningful dependence between soil loss, trail slope ratio and trail slope alignment. The maximum incision is only significantly dependent when compared to trail and landform grade. Trail width decreases with increasing elevation on average due to a smaller number of visitors (the higher elevation, the narrower trail). For maximum incision the dependence is positive (incision is in average greater for higher elevation) - influence of rough weather and missing forest canopy (susceptibility to erosion).

\subsection{Decision trees}

Because interpretation of results is rather complicated we also tested data mining decision trees to gain meaningful insights. For modeling tread width dependence, the tree diagram (Fig. 5) shows that the use level is the best (i.e., the most significant) predictor of tread width. The proportion of tread width variance explained by CRT is $55 \%$, which indicates a good model.

\section{Discussion and management implications}

National Park Service units are charged with providing opportunities for recreation along with the protection and preservation of natural and cultural resources and ecological 


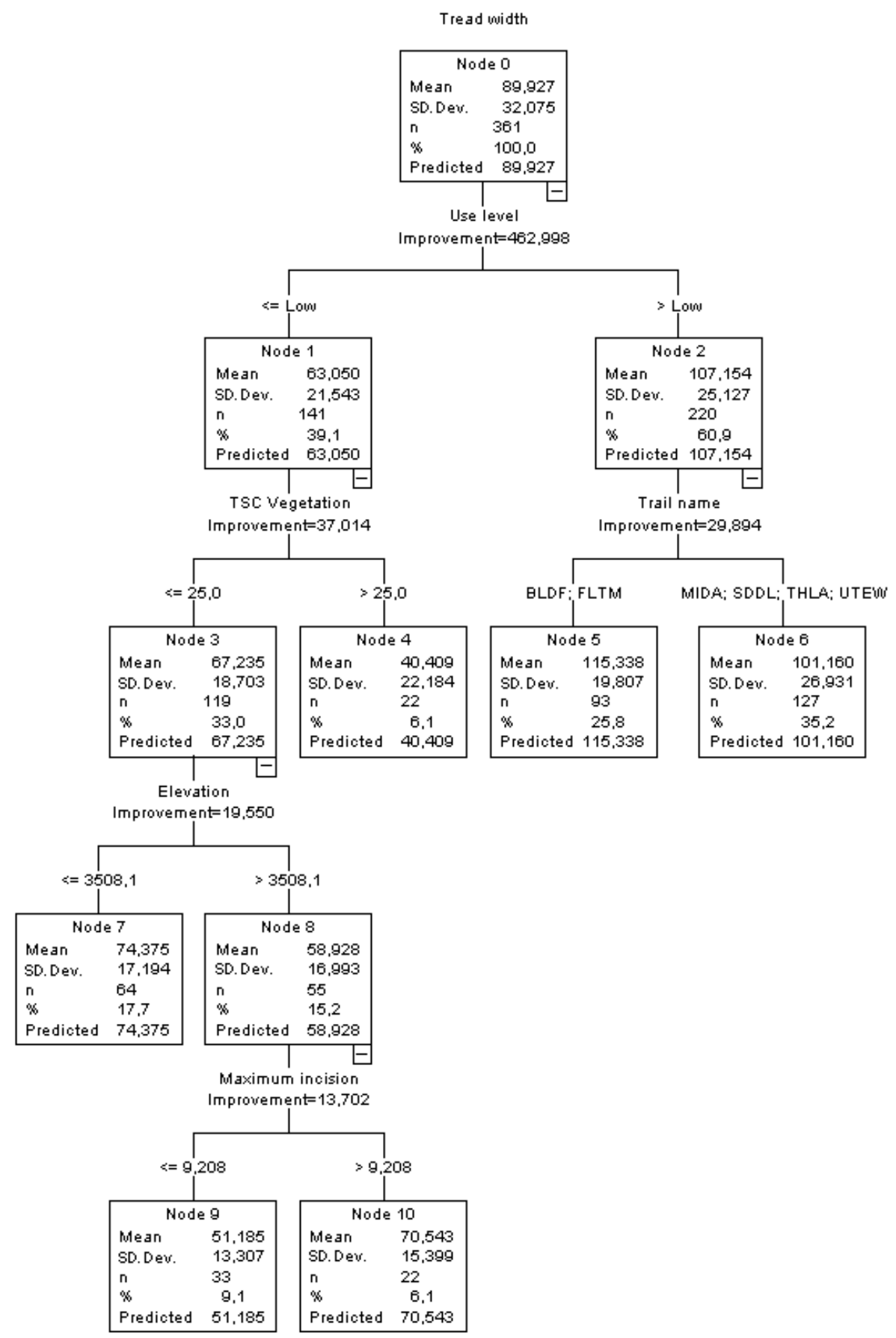

Figure 5. CRT regression tree of tread width.

processes. This research provides information on the impacts of visitor use to trails and which abiotic factors are the most influential on trail conditions. This type of information can serve as the basis for the management of visitors. This research used a variety of trail inventory and impact indicators to understand trail conditions, while also providing a baseline to assess future trail conditions against, as it serves as data for the current condition of trails (see example in Fig. 6). These data could also be used for the evaluation of trail condition trends over time which allows for more informed management decisions to be made in the future.

During the initial literature review, we found many studies related to trail impacts monitoring and trail indicators. Dixon et al. (2004) proposed the use of two trail indicators - track depth and track width - to understand trail conditions. Their analysis revealed that track depth and rates of 


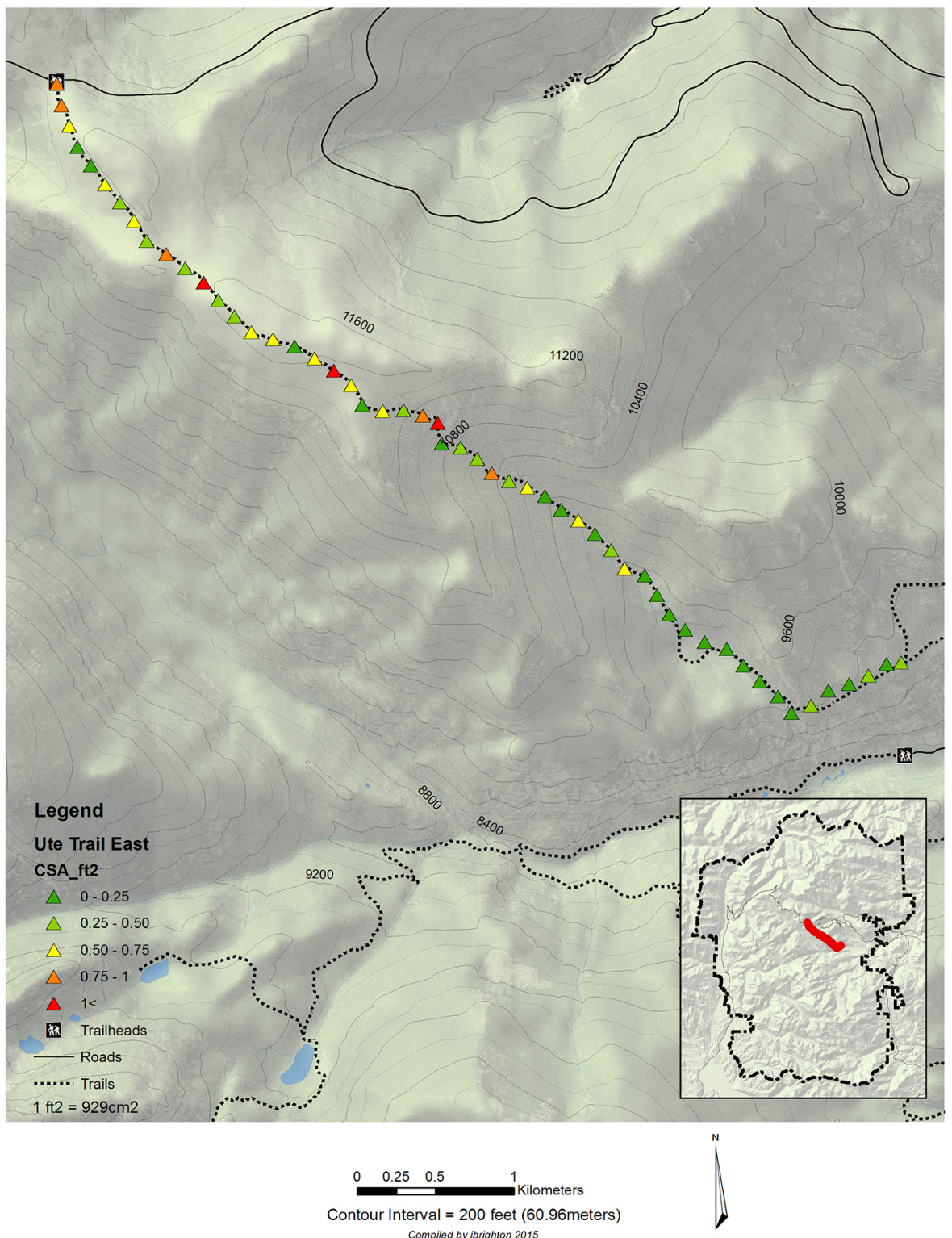

Figure 6. Example of soil loss volume on evaluated trails, indicating the worst points to managers.

erosion are strongly influenced by track type and to a lesser extent by usage, while track width is influenced mainly by usage and track bogginess. Slope of the path and the number of visitors were two main factors explaining trail width and depth in other studies (Selkimaki and Mola-Yudego, 2011). Tomczyk and Ewertowski (2013) discovered that no connection was demonstrated between amount (number of visitors) or type of trail use and the amount of soil loss or deposition a trail underwent. A study by Jubenville and O'Sullivan (1987) concluded that vegetation type and slope gradient to trail erosion explained not much of variance in soil loss (could be explained by trail design and permafrost in Alaska). Nepal (2003) found that trails tend to be more degraded at higher altitude and on steep gradients, along with a strong positive correlation between trail degradation and frequencies of visitor use. Nepal and Nepal (2004) also found a strong correlation between visitor use and trail degradation. However, locational and environmental factors are equally important variables. The study concludes that more systematic and experimental studies are needed that can make a clear distinction between human-induced trail damage and the effects of natural factors. Trail grade and trail slope alignment angle, which often impact trail width and soil loss, were the two most important inventory indicators (Dissmeyer and Foster, 1984; Aust et al., 2004) assessed in the survey. Trails located in flatter terrain can be susceptible to widening and muddiness problems due to drainage issues. Fallaligned trails are of particular concern due to their increased 
potential for erosion. This study found that trail alignment tends to be more influential on soil loss than the predominant type of visitor use (e.g., horse vs. hiker traffic) or number of users. We also assumed that soil loss increases exponentially with steeper trail grade, though the natural rockiness of RMNP's trail treads and stonework in our case probably limit erosion and help sustain steeper trail sections. Soil loss, attributable to several causal factors, was assessed for the trails using three measures: mean trail depth $(7.1 \mathrm{~cm})$, maximum incision $(19.0 \mathrm{~cm})$ and cross-sectional area $\left(444.5 \mathrm{~cm}^{2}\right)$. Relational analyses for soil loss revealed that level of trail use and trail grade had the most influence, however dependence with trail slope alignment angle was not significant as other studies found (e.g., Wimpey and Marion, 2010). Ólafsdóttir and Runnström (2013) discovered, after analyzing several physical properties, that only elevation has a clear relationship with hiking trail condition in their study sites. Severe conditions never apply to a whole trail, suggesting that trail conditions are a function of trampling magnitude and local physical properties. Hence, when maintaining hiking trails in vulnerable environments, a holistic understanding of the effects of trampling is critical for trail sustainability.

When comparing two types of recreational visitor use (hikers and horseback riders), our results indicated that medians were greater for trail width, maximum incisions and soil loss in case of trails that allowed horseback riders. This shows that horse use within the park generally increases impacts on the trail system when looking at specific indicators in specific locations. It is compatible with results of other studies. Pack animals, according to Barros and Pickering (2015), caused more damage than hikers to the alpine meadow and their impacts were apparent at a lower level of use than for hikers. Horse traffic also consistently made more sediment available for erosion from llamas, hikers or no traffic (Deluca at al., 1998). It is also important to notice that horse riding trails can promote exotic plant species, many of which are not native to the area, which may lead to changes in the structure of vegetation communities (Törn et al., 2009).

Fall-aligned trails, with steeper grades, frequently require significant investments in rockwork and maintenance to keep them sustainable and to keep them from widening. This is especially true in areas prone to freeze/thaw and water runoff. Trail width can also be influenced by many other variables including use level, visitor behavior, trail grade, landform grade, trail ruggedness and trail borders. Wimpey and Marion (2010) found the relationship of trail width was most associated with trail and landform grade and trail slope alignment since steeper grade restricted lateral dispersion of hikers. Our results confirm that trail width is predominantly a function of use level. Mean trail width is a relatively wide $89.9 \mathrm{~cm}$, though many trails are purposefully designed with wider widths to support heavy visitor use. A trail width difference with a mean of $22.6 \mathrm{~cm}$ indicates that the formal trails are generally wider than intended. Other important factors we found were the behavior of visitors and absence of trail borders. Trails without borders will lead to further widening, since visitors have a hard time discerning where the trail is located. The ruggedness of a trails' tread can also encourage the widening of trails, since hikers often look for easier passage to avoid these areas which are often along trail sides. To address these issues, managers can manipulate the level of trail use, create trail borders or educate visitors on how to decrease their impact on trails. These solutions are easily implemented and relatively cost-effective. An obvious solution for managers to prevent soil loss would be to control use levels, though this is often not popular with visitors and does not act as part of the park's mission to allow access. A second option would be to relocate trails located in areas highly prone to soil loss. Wilderness values may inhibit relocations of trails so this might be an option that could be used only in select locations (excessively steep or aligned closely to the fall line). A third option is to shorten the time between regular maintenance visits for each trail (Birchard and Proudman, 2000). This option would likely be the least economic and have impacts on visitation and wilderness due to the more frequent presence of workers or closures of trails for work. Some authors commonly recommend preventing soil loss by keeping grades of less than 10-12\% (Hooper, 1988; Hesselbarth et al., 2007), trail slope alignment higher than $22^{\circ}$ (Olive and Marion, 2009) and trail slope ratio less than 0.5 (IMBA, 2004). Our survey found that $24 \%$ of the evaluated trails exceed a grade of $15 \%$. Additionally, only $6 \%$ of the evaluated trails are aligned within $22^{\circ}$ of the fall line, which makes the dispersion of water more challenging and thus increases soil erosion. Soil erosion would likely have been much higher than assessed if not for the substantial amount of granitic rock in the soils and the extensive use of rock steps - see also Fig. 2. Moore et al. (2012) stated that unmaintained trail impacts are negatively perceived by visitors and have an overall adverse effect on visitor experiences, providing support for proper trail design and maintenance. Ballantyne et al. (2014) recommended that management should seek to minimize the creation of informal trails by hardening popular routes and centralizing visitor flow. Different walking track types can have an effect on different vegetation characteristics (Hill and Pickering, 2006). In some cases closure of recreational sites and trails can be a solution for trail degradation. However, to improve soil properties, long periods of closure are necessary due to slow soil-forming processes (Özcan et al., 2013; Sharratt et al., 1998; Brevik and Fenton, 2012). Another option is the importance role of trampling tolerant vegetation communities which can be both resistant and resilient to increased use (Pickering and Growcock, 2009). Restoring damage to natural vegetation and soils by human use in alpine environments can be extremely challenging due to the severity of the environment which restricts plant growth and increases the potential for soil erosion (Scherrer and Pickering, 2006).

Regarding methods, a distance-based technique, in which measurements are made at regular spatial intervals, is quite time-consuming. A technique of sampling at $20 \mathrm{~m}$ intervals 
can be used to assess typically 5-7 km of track per day in remote areas (Hawes et al., 2006). Our experiences confirmed time consumption so there will be fair discussion about practicality to repeat these measurements as a part of a potential monitoring program. A combination with GIS-based methodologies could be a more effective tool (Hawes et al., 2013; Ballantyne et al., 2014; Ólafsdóttir and Runnström, 2013) to examine the relationship between trail condition assessment and local physical properties, such as elevation, gradient, soil type and vegetation cover. For further trail monitoring, a recommendation to consider is the possibility of increasing precision of measurements (submeter accuracy GPS units, smaller intervals for measurements between sampling points of $30 \mathrm{~m}$; this will increase time capacity). Lidarderived terrain models could greatly speed up collection of measurements (Nadal-Romero et al., 2015). Maximum incision and trail width are the most significant predictors of CSA which can be used for simplifying during measurements. Measurements of CSA could be influenced as well by boundary determinations (historic vs. recent erosion). Trail work prior to this study could have also impacted the precision of measurements taken. For example, previous side-hill work along the trail may have also altered the final estimation of soil loss since these practices would have helped keep soil in place. It is also important to add the presence of a trail border into the point sampling from what can be used for analysis, especially with the trail width indicator. Contrary to the original methodology for simplification, we slightly modified categories of trail surface.

\section{Conclusions}

This study has set out to understand and assess impacts on the trail network of the RMNP study area to gain information on how abiotic factors such as grade, elevation, surface type and trail slope alignment can influence trail conditions. Additionally, we looked at how visitation type (e.g., people vs. horses) and level of use impacted trails and finally, we wanted to determine which factors were most important and what connection between factors existed. This information could then be used to help managers reduce the effects of increased visitor use on trails and other resources of the park.

After assessing the trail conditions within the study area we found that grade, elevation, surface type and trail slope alignment were all important factors to determine trail degradation. It does appear that certain factors, such as trail slope alignment, are more important than others when considering soil loss or trial widening. Furthermore, factors such as grade and elevation are important factors when considering loss of vegetation. We would recommend that any robust trail monitoring program would include monitoring all the aforementioned trail indicators and factors.

When we looked at the different types and volume of trail usage, only factors such as maximum incision, trail width and soil loss were considerably affected. Horse trails tended to be more incised, wider and had more soil loss than trails closed to horses, meaning use type was important to consider when maintaining or constructing trails. When looking at how use levels impact trail conditions, only one indicator was impacted significantly - tread width - meaning that more users only seem to make trails wider. This make sense since there will be more users passing by each other along the trail.

We believe that any solid trail monitoring program would use all trail indicators and factors mentioned. Each factor and indicator is either directly or indirectly connected to each of the others, so omitting any may increase the likelihood of misunderstanding what is causing trail degradation. For example, trail slope alignment and grade together were the strongest indicators for predicting soil loss, though indicators such as usage type also impacted soil loss. As visitation of protected areas is going to increase as populations grow and face new challenges from changing climates, it is important to continue to monitor, learn and adapt if these areas are to remain accessible while protecting the valuable resources found within them.

Acknowledgements. Authors would like to thank Rocky Mountain National Park for their support and technical assistance during fieldwork, the Slovak-American Foundation for financing research and publication of results, Jeff Marion, Yu-Fai Leung, Jeff Connor and anonymous reviewers for valuable advice concerning methodology and the first version of manuscript. This research was also supported by the VEGA project no. 1/0411/14, "Tourist visitation as a factor influencing the diversity of organisms in protected areas".

Edited by: A. Cerdà

\section{References}

Aust, M. W., Marion, J. L., and Kyle, K.: Research for the Development of Best Management Practices for Minimizing Horse Trail Impacts on the Hoosier National Forest, Management Report, US Department of Agriculture, US Forest Service, Bedford, IN, USA, 77 pp., 2004.

Ballantyne, M. and Pickering, C. M.: Recreational trails as a source of negative impacts on the persistence of keystone species and facilitation, J. Environ. Manage., 159, 48-57, 2015.

Ballantyne, M., Gudes, O., and Pickering, C. M.: Recreational trails are an important cause of fragmentation in endangered urban forests: a case-study from Australia, Landscape Urban Plan., 130, 112-124, 2014.

Barros, A. and Pickering, C. M.: Impacts of experimental trampling by hikers and pack animals on a high-altitude alpine sedge meadow in the Andes, Plant Ecol. Divers., 8, 265-276, 2015.

Barros, A., Monz, C., and Pickering, C.: Is tourism damaging ecosystems in the Andes? Current knowledge and an agenda for future research, Ambio, 44, 82-98, 2015.

Benninger-Truax, M., Vankat, J. L., and Schaefer, R. L.: Trail corridors as habitat and conduits for movement of plant species 
in Rocky Mountain National Park, Colorado, USA, Landscape Ecol., 6, 269-278, 1992.

Birchard, W. and Proudman, R. D.: Appalachian Trail Design, Construction, and Maintenance, 2nd edition, Appalachian Trail Conference, Harpers Ferry, WV, USA, 237 pp., 2000.

Brevik, E. C. and Fenton, T. E.: Long-term effects of compaction on soil properties along the Mormon Trail, South-Central Iowa, USA, Soil. Horiz., 53, 37-42, 2012.

Bright, J. A.: Hiker impact on herbaceous vegetation along trails in an evergreen woodland of Central Texas, Biol. Conserv., 36, 53-69, 1986.

Chrisfield, V. E., Macdonald, S. E., and Gould, A. J.: Effects of recreational traffic on alpine plant communities in the northern Canadian Rockies, Arct. Antarct. Alp. Res., 44, 277-287, 2012.

Cole, D. N.: Assessing and monitoring backcountry trail conditions, Research Paper INT-303, US Department of Agriculture, Forest Service, Intermountain Research Station, Ogden, UT, USA, 10 pp., 1983.

Cole, D. N.: Low-impact recreational practices for wilderness and backcountry, General Technical Report INT-265, US Department of Agriculture, Forest Service, Intermountain Research Station, Ogden, UT, USA, 131 pp., 1989.

Deluca, T., Patterson Iv, W., Freimund, W. A., and Cole, D.: Influence of llamas, horses, and hikers on soil erosion from established recreation trails in western Montana, USA, Environ. Manage., 22, 255-262, 1998.

Dissmeyer, G. E. and Foster, G. R.: A guide for predicting sheet and rill erosion on forestland, General Technical Publication R8-TP 6, US Department of Agriculture, Forest Service, Atlanta, GA, USA, 40 pp., 1984.

Dixon, G., Hawes, M., and McPherson, G.: Monitoring and modeling walking track impacts in the Tasmanian wilderness World Heritage Area, Australia, J. Environ. Manage., 71, 305-320, 2004.

Farrell, T. A. and Marion, J. L.: Trail impacts and trail impact management related to visitation at Torres del Paine National Park, Chile, Leisure, 26, 31-59, 2001.

Godefroid, S. and Koedam, N.: The impacts of forest paths upon adjacent vegetation: Effects of the path surfacing material on the species composition and soil compaction, Biol. Conserv., 119, 405-419, 2004.

Gonzalez, P.: Climate Change Trends and Impacts for Planning at Rocky Mountain National Park, National Park Service, Natural Resource Stewardship and Science, Washington, DC, 7 pp., 2012.

Hammitt, W. E., Cole, D. N., and Monz, C. A.: Wildland recreation: ecology and management, Wiley, New York, USA, 328 pp., 2015.

Hawes, M., Candy, S., and Dixon, G.: A method for surveying the condition of extensive walking track systems, Landscape Urban Plan., 78, 275-287, 2006.

Hawes, M., Dixon, G., and Ling, R.: A GIS-based methodology for predicting walking track stability, J. Environ. Manage., 115, 295-299, 2013.

Hesselbarth, W., Vachowski, B., and Davies, M. A.: Trail construction and maintenance notebook, Tech. Rpt. 0723-2806-MTDC, US Department of Agriculture Forest Service, Missoula Technology and Development Center, Missoula, MT, USA, 2007.
Hill, W. and Pickering, C.: Vegetation associated with different walking track types in the Kosciuszko alpine area, Australia, J. Environ. Manage., 78, 24-34, 2006.

Hill, W. and Pickering, C.: Comparison of condition class, point sampling and track problem assessment methods in assessing the condition of walking tracks in New South Wales protected areas, CRC for Sustainable Tourism Pty Ltd., Queensland, Australia, 2009.

Hooper, L.: National Park Service Trails Management Handbook, USD1 National Park Service, Denver Service Center, Denver, CO, USA, 53 pp., 1988.

Ibáñez, J. J., Pérez-Gómez, R., Oyonarte, C., and Brevik, E. C.: Are there arid land soilscapes in Southwestern Europe?, Land Degrad. Develop., 26, 785-862, 2015.

IMBA: Trail Solutions: IMBA's guide to building sweet singletrack, The International Mountain Bike Association, Boulder, CO, USA, 2004.

IRMA: National Park Service Visitor Use Statistics, Integrated Resource Management Applications, https://irma.nps.gov/Stats/ (last access: 30 June 2015), 2014.

Jewell, M. C. and Hammitt, W. E.: Assessing soil erosion on trails: a comparison of techniques, in: Proceedings RMRS, Wilderness Science in a Time of Change Conference, Volume 5: Wilderness ecosystems, threats, and management, Missoula, Montana, USA, 23-27 May 1999, United States Department of Agriculture, Forest Service, Rocky Mountain Research Station, Ogden, UT, USA, 133-140, 2000.

Jubenville, A. and O'Sullivan, K.: Relationship of vegetation type and slope gradient to trail erosion in interior Alaska, J. Soil Water Conserv., 42, 450-452, 1987.

KellerLynn, K.: Impacts of path surfaces on surrounding vegetation, Park Science, 24, p. 21, 2006.

Kim, S.-O. and Shelby, B.: Comparing onsite and offsite methods for measuring norms for trail impacts, Environ. Manage., 37, 567-578, 2006.

Lance, A. N., Baugh, I. D., and Love, J. A.: Continued footpath widening in the Cairngorm mountains, Scotland, Biol. Conserv., 49, 201-214, 1989.

Leung, Y. F. and Marion, J. L.: Recreation impacts and management in wilderness: a state of knowledge review, in: Proceedings RMRS, Wilderness Science in a Time of Change Conference, Volume 5: Wilderness ecosystems, threats, and management, Missoula, Montana, USA, 23-27 May 1999, United States Department of Agriculture, Forest Service, Rocky Mountain Research Station, Ogden, UT, USA, 23-48, 2000.

Manning, R.: Studies in Outdoor Recreation. Search and research for satisfaction, 2nd edition, Oregon State University Press, Corvallis, OR, USA, 1999.

Marion, J. L. and Leung, Y. F.: Trail resource impacts and an examination of alternative assessment techniques, Journal of Park and Recreation Administration, 19, 17-37, 2001.

Marion, J. L., Wimpey, J., and Park, L.: Informal and formal trail monitoring protocols and baseline conditions: Acadia National Park, final report, US Geological Survey, Virginia Tech College of Natural Resources and Environment, Blacksburg, VA, USA, 95 pp., 2011.

McCool, S. F. and Lime, D. W.: Tourism carrying capacity: tempting fantasy or useful reality?, J. Sustain. Tour., 9, 372-388, 2001. 
Monti, P. W. and MacKintosh, E. E.: Effects of camping on surface soil properties in the boreal forest region of Northwestern Ontario, Canada, Soil Sci. Soc. Am. J., 43, 1024-1029, 1979.

Monz, C. A.: Recreation resource assessment and monitoring techniques for mountain regions, in: Tourism and development in mountain regions, edited by: Godde, P. M., Price, M., and Zimmermann, F. M., CABI Publishing, Oxon, UK, 47-68, 2000.

Monz, C. A., Pickering, C. M., and Hadwen, W. L.: Recent advances in recreation ecology and the implications of different relationships between recreation use and ecological impacts, Front. Ecol. Environ., 11, 441-446, 2013.

Moore, R. L., Leung, Y.-F., Matisoff, C., Dorwart, C., and Parker, A.: Understanding users' perceptions of trail resource impacts and how they affect experiences: an integrated approach, Landscape Urban Plan., 107, 343-350, 2012.

Nadal-Romero, E., Revuelto, J., Errea, P., and López-Moreno, J. I.: The application of terrestrial laser scanner and SfM photogrammetry in measuring erosion and deposition processes in two opposite slopes in a humid badlands area (central Spanish Pyrenees), SOIL, 1, 561-573, doi:10.5194/soil-1-561-2015, 2015.

Nepal, S.: Trail impacts in Sagarmatha (Mt. Everest) National Park, Nepal: a logistic regression analysis, Environ. Manage., 32, 312321, 2003.

Nepal, S. K. and Nepal, S. A.: Visitor impacts on trails in the Sagarmatha (Mt. Everest) National Park, Nepal, Ambio, 33, 334-340, 2004.

NPS: State of the Alpine Report for Rocky Mountain National Park Summary Report, USDI National Park Service Fort Collins, Colorado, USA, 42 pp., 2010.

Ólafsdóttir, R. and Runnström, M.: Assessing hiking trails condition in two popular tourists' destination in the Icelandic highlands, Journal of Outdoor Recreation and Tourism, 3-4, 57-67, 2013.

Olive, N. D. and Marion, J. L.: The influence of use-related, environmental and managerial factors on soil loss from ecreational trails, J. Environ. Manage., 90, 1483-1493, 2009.

Özcan, M., Gökbulak, F., and Hizal, A.: Exclosure effects on recovery of selected soil properties in a mixed broadleaf forest recreation site, Land Degrad. Dev., 24, 266-276, 2013.

Pettebone, D., Newman, P., and Theobald, D.: A comparison of sampling designs for monitoring recreational trail impacts in Rocky Mountain National Park, Environ. Manage., 43, 523-532, 2009.

Pickering, C. M. and Growcock, A. J.: Impacts of experimental trampling on tall alpine herbfields and subalpine grasslands in the Australian Alps, J. Environ. Manage., 91, 532-540, 2009.

Pickering, C. M., Hill, W., Newsome, D., and Leung, Y.-F.: Comparing hiking, mountain biking and horse riding impacts on vegetation and soils in Australia and the United States of America, J. Environ. Manage., 91, 551-562, 2010.
RMNP: Trail System Maintenance and Reconstruction Plan 2000, an update to the May 1982 Trail Plan, USDI National Park Service, RMNP Colorado, CO, USA, 164 pp., 2000.

RMNP: Backcountry/Wilderness Management Plan, USDI National Park Service, RMNP Colorado, CO, USA, 75 pp., 2001.

RMNP: Employee and Volunteer Handbook, RMNP Colorado, CO, USA, 155 pp., 2013.

Scherrer, P. and Pickering, C. M.: Recovery of alpine herbfield on a closed walking track in the Kosciuszko Alpine Zone, Australia, Arct. Antarct. Alp. Res., 38, 239-248, 2006.

Selkimaki, M. and Mola-Yudego, B.: Estimating and modelling the resistance of nature to path erosion in Koli National Park, Finland, Boreal Environ. Res., 16, 218-228, 2011.

Sharratt, B. S., Voorhees, W. B., McKintosh, G., and Lemme, G.: Persistance of soils structural modifications along a historic wagon trail, Soil Sci. Soc. Am. J., 62, 774-777, 1998.

Summer, R. M.: Geomorphic impacts of horse traffic on montane landforms, J. Soil Water Conserv., 41, 126-128, 1986.

Tomczyk, A. M. and Ewertowski, M.: Degradation of recreational trails, Gorce National Park, Poland, Journal of Maps, 7, 507-518, 2011.

Tomczyk, A. M. and Ewertowski, M.: Quantifying short-term surface changes on recreational trails: the use of topographic surveys and "Digital Elevation Models of Differences" (DODs), Geomorphology, 183, 58-72, 2013.

Törn, A., Tolvanen, A., Norokorpi, Y., Tervo, R., and Siikamäki, P.: Comparing the impacts of hiking, skiing and horse riding on trail and vegetation in different types of forest, J. Environ. Manage., 90, 1427-1434, 2009.

Vistad, O. I.: Experience and management of recreational impact on the ground-a study among visitors and managers, J. Nat. Conserv., 11, 363-369, 2003.

Washburn, R. F.: Wilderness recreation carrying capacity: are numbers necessary?, J. Forest., 80, 726-728, 1982.

Willard, B. E. and Marr, J. W.: Effects of visitors on natural ecosystems in ROM O, Final report on 1959-1963 study, unpublished, Institute of Arctic Alpine Res, University of Colorado, Boulder, CO, USA, 1963.

Wilson, J. P. and Seney, J. P.: Erosional impact of hikers, horses, motorcycles, and off-road bicycles on mountain trails in Montana, Mt. Res. Dev., 14, 77-88, 1994.

Wimpey, J. and Marion, J. L.: The Influence of use, environmental and managerial factors on the width of recreational trails, J. Environ. Manage., 91, 2028-2037, 2010.

Zdruli, P.: Land resources of the Mediterranean: status, pressures, trends and impacts on future regional development, Land Degrad. Develop., 25, 373-384, 2014. 